\title{
PROBING IN VITRO TRANSLATION PRODUCTS WITH MONOCLONAL ANTIBODIES TO CHLOROPHYLL $a / b$-BINDING PROTEINS OF BARLEY THYLAKOIDS
}

\author{
by \\ GUNILLA HØYER-HANSEN, LISBETH SKOU HØNBERG ${ }^{1)}$ and ROBERTO BASSI ${ }^{2)}$
}

\author{
Department of Physiology, Carlsberg Laboratory, \\ Gamle Carlsberg Vej 10, DK-2500 Copenhagen Valby \\ 1/Present address: Department of Animal Physiology \& Biochemistry, \\ Foulum Research Center, DK-8833 Ørum, Sønderlyng, Denmark \\ 2Present address: Dipartimento di Biologia, Universitá di Padova, \\ Via Orto Botanico 35, I-35100 Padova, Italy
}

Keywords: Immunoblotting, mRNA, viridis- $k^{23}$, xantha- $l^{35}$

\begin{abstract}
The polypeptides of the barley light-harvesting protein of photosystem I (LHCl) share certain epitopes. At least two of these common epitopes are present in chlorophyll $a / b$-protein $1\left(\mathrm{Ch}_{a / h}-\mathrm{Pl}=\mathrm{CP} 29\right)$, as shown by cross-reacting monoclonal antibodies (14). These antibodies were employed for immunological identification of polypeptides translated in vitro in an mRNA-dependent cell-free rabbit reticulocyte lysate. The monoclonal antibody CMpLHCI:2 precipitated only one polypeptide of molecular weight $28 \mathrm{kD}$ from in vitro translates primed with polyA+ RNA. No $28 \mathrm{kD}$ precipitation band was found, if this antibody was mixed with a PSI-200 preparation before it was added to the translate. The translational capacity of the LHCI transcripts isolated from 12 hours greened barley was much higher than those isolated from 6 hours greened barley. Transcripts for LHCI polypeptides were also found among the poly ${ }^{+}$RNA of the mutant viridis- $k^{23}$, which is devoid of LHCI polypeptides in its thylakoid membranes.

The monoclonal antibody $\mathrm{CMpChl}_{a / h}-\mathrm{P} 1: 1$ precipitated a polypeptide of molecular weight $31 \mathrm{kD}$ from in vitro translates primed with polyA ${ }^{+}$RNA. Thus, the cross-reactivity the two antibodies show with the mature proteins is not found when the antibodies are reacted with the precursor proteins.
\end{abstract}

\section{INTRODUCTION}

The chlorophyll $a / b$-binding proteins in the thylakoids have a light-harvesting function. In barley photosystem I (PSI) preparations isolated by Triton X-100 solubilisation of thylakoids yield upon sucrose gradient centrifugation two chlorophyll $a / b$-binding proteins. They are identified by their low-temperature fluorescence emission spectra and are named LHCI-680 and LHCI-730 $(2,4,17)$. Photosystem II (PSII)

Abbreviations: Chl-P = Chlorophyll-protein; CM - Carlsberg Monoclonals; $\mathrm{cpm}=$ counts per minute; DNA = deoxyribonucleic acid; DTT = dithiothreitol; $\mathrm{kD}=$ kilodalton; $\mathrm{LHC}=$ light-harvesting complex; PAGE = polyacrylamide gel electrophoresis; PS = photosystem; PSI-200 = PSI containing LHCI polypeptides; polyA = polyadenylated; RNA = ribonucleic acid; $\mathrm{SDS}=$ sodium dodecyl sulphate; $\mathrm{TCA}=$ trichloroacetic acid; $\mathrm{WT}=$ wild-type. 


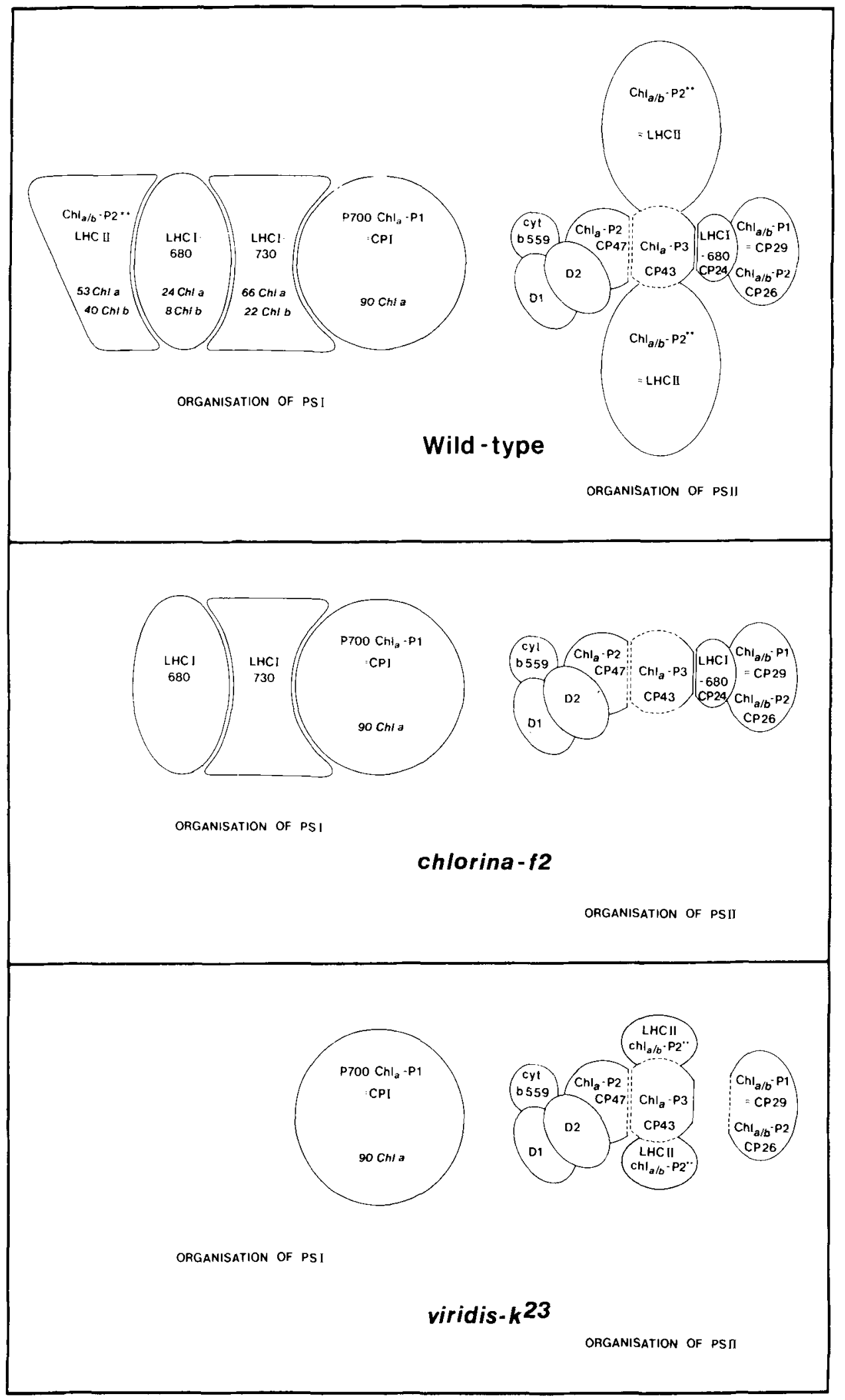


Figure 1. Schematic representation of the chlorophyll-proteins of photosystem I and II of wild-type barley and the two nuclear gene mutants chlorina- $f 2$ and viridis- $k^{23}$.

preparations from maize have recently been shown to contain four chlorophyll $a / b$-binding proteins. If the major one is maintained in its oligomeric form as $\mathrm{LHCII}^{* *}$, the three others can be resolved. They are $\mathrm{Chl}_{a / b}-\mathrm{P} 1$ (CP29), $\mathrm{CP} 26$ and $\mathrm{CP} 24$, the latter probably being identical to LHCI-680 (3).

The major chlorophyll $a / b$-binding protein, LHCII, is absent from the thylakoids of the chlorophyll $b$-less barley mutant, chlorina- 2 (18) even though the polypeptides can be detected with an immunoblot assay (20). Interestingly, the polypeptides corresponding to those in $\mathrm{Chl}_{a / b}-\mathrm{Pl}$ and LHCI are present in chlorina- 2 and bind chlorophyll $a$ (14). A contrasting phenotype with the absence of LHCI is exhibited by the barley nuclear gene mutant viridis- $k^{23}$. The mutant has a leaky block in the conversion of Mg-protoporphyrin IX to protochlorophyllide resulting in a chlorophyll content of only $25 \%$ of that of the wild-type but with some chlorophyll $b$ present $(\mathrm{Chl} a / b$ ratio $=10)(8)$. The mutant lacks the long wave-length $(730 \mathrm{~nm})$ fluorescence emission at $77 \mathrm{~K}$, indicating the loss of LHCI-730 (21). Figure 1 shows a schematic representation of the organisation of chlorophyll-proteins in wild-type and the two mutants (22).

The polypeptides of the different chlorophyll $a / b$-proteins have structurel similarities as evidenced by antibody cross-reactivity. There have been reported polyclonal antibodies to LHCI that react with LHCII (6) and monoclonal antibodies raised to $\mathrm{LHCII}$ that reacts with LHCI (5). There have also been raised both mono- and polyclonal antibodies to $\mathrm{LHCI}$, that react with $\mathrm{Chl}_{a / b}-\mathrm{Pl}$ and vice versa $(14,26)$.

We have previously described monoclonal antibodies to $\mathrm{LHCI}$ and $\mathrm{Chl}_{a / b}-\mathrm{Pl}$ that show mutual cross-reactivity (14). In this study we have employed these antibodies for immunoprecipitation of in vitro translated polypeptides, using polyA ${ }^{+}$RNA isolated from both wild-type and the LHCI-less mutant viridis- $k^{23}$. For comparison we have investigated another nuclear gene mutant, xantha- $l^{35}$, which is also partially blocked in the conversion of Mg-protoporphyrin IX to protochlorophyllide, but not allelic to viridis- $k^{23}(25)$.

\section{MATERIALS AND METHODS}

\subsection{Plant material}

Seeds of wild-type barley (Hordeum vulgare $\mathrm{cv}$. Svalof's Bonus) and the nuclear gene mutants viridis $k^{23}$ and xantha- $l^{35}$ were germinated in tap-water-moistened vermiculite and grown in the light ( 1700 lux) at $23{ }^{\circ} \mathrm{C}$ for 7 days. The mutant seedlings were separated from the wildtype by their paler green colour. For isolation of etioplast membranes, wild-type was also grown for 7 days in the dark at $23^{\circ} \mathrm{C}$. Wild-type and mutant seedlings used for isolation of RNA were grown for 6 days in the dark followed by 12 hours in the light (1700 lux). In addition, wildtype seedlings were harvested after 6 hours of illumination.

\subsection{Isolation of thylakoids and PSI-200}

Internal plastid membranes were purified by flotation in a discontinuous sucrose gradient (11). The membranes were stored in $0.1 \mathrm{M}-\mathrm{Na}$ $\mathrm{CO}_{3}-0.1 \mathrm{M}$-dithiothreitol (DTT) at $-80{ }^{\circ} \mathrm{C}$. A PSI preparation, containing the $\mathrm{LHCl}$ polypeptides, PSI-200, was isolated by Triton X-100 solubilisation of thylakoids followed by sucrose gradient ultra-centrifugation (4). Chlorophyll was determined according to ARNON (1).

\subsection{Sodium dodecyl sulphate polyacrylamide gel electrophoresis (SDS-PAGE), immunoblot assay and monoclonal antibodies}

Electrophoresis in SDS was performed as described by FLING and GREGERSON (7), separating the polypeptides in an $8-25 \%$ polyacrylamide gradient. Immediately after completion of the electrophoretic run, the polypeptides were 


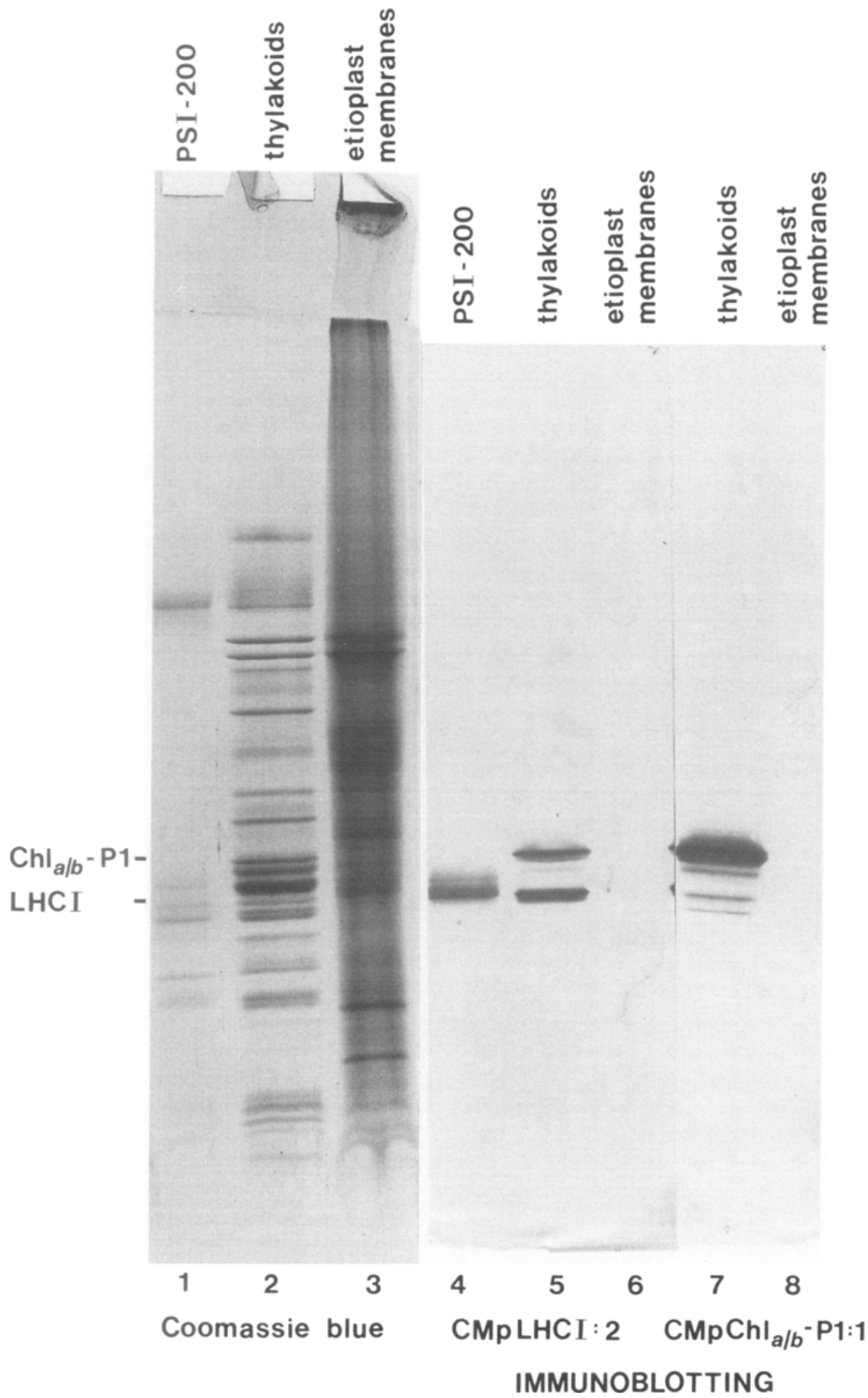


Figure 2. Absence of $\mathrm{LHCl}$ and $\mathrm{Chl}_{a / h}-\mathrm{Pl}$ in etioplasts.

The antigen for the production of monoclonal antibodies to LHCl, PSI-200, chloroplast ( $20 \mu \mathrm{g} \mathrm{Chl})$ and etioplast membrane polypeptides were separated on 8-25\% SDS-PAGE. Lanes 1, 2 and 3 are stained with Coomassie blue. Lanes 4-8 are nitrocellulose sheets after electro-blotting. Lanes 4, 5 and 6 were probed with $150 \mu \mathrm{g}$ of CMpLHCl:2 and lanes 7 and 8 were incubated with $75 \mu \mathrm{g}$ of $\mathrm{CMpChl}_{a / b}-\mathrm{Pl}: 1$. The lanes with etioplast membrane polypeptides were heavily overloaded to assure detection of minute amounts of $\mathrm{LHCl}$ and $\mathrm{Ch}_{a / b}-\mathrm{Pl}$.

transferred from the SDS-gel to nitrocellulose filters $(10,12,24)$. These were used for immunoblot assays as previously described (12). Immobilized antigens were visualized using peroxidase-coupled rabbit antimouse immunoglobulins (Dakopatts A/S, Copenhagen, Denmark, P161). The antibodies to LHCI and chlorophyll $a / b$-protein 1 (CP29) were CMpLHCI:2 and $\mathrm{CMpCh}_{a / b}-\mathrm{Pl}: 1$. They are described earlier (14).

\subsection{Isolation of $\mathrm{mRNA}$, in vitro translation and immunoprecipitation}

RNA was prepared exactly as described earlier (13). The isolated RNA was used to prime in vitro translation using rabbit reticulocyte lysate (Amersham N.90) and ${ }^{35} \mathrm{~S}$-methionine (New England Nuclear). The optimal amount of RNA for each translation was determined by titration.

The immunoprecipitations were performed as previously detailed (13). Each precipitation started with material containing at least $10^{6}$ acid precipitable cpm. The apparent molecular weights of the immunoprecipitated polypeptides were estimated by co-electrophoresis with ${ }^{14} \mathrm{C}$-methylated molecular weight standards (Amersham CFA626) lysozyme (14.3 kD), carbonic anhydrase $(30 \mathrm{kD})$, ovalbumin $(46 \mathrm{kD})$, bovine serum albumin $(69 \mathrm{kD})$, phosphorylase $b(92.5 \mathrm{kD})$ and myosin $(200 \mathrm{kD})$.

\section{RESUITS}

The polypeptides of $\mathrm{LHCI}$ and $\mathrm{Chl}_{a / b}-\mathrm{Pl}$ are not detected in etioplast membranes of barley (Figure 2, lanes 6 and 8). However, they are present in the internal membranes of the greening plastid already after a few hours of illumination. This is revealed when the thylakoid mem- brane polypeptides from plants, that had received light for 6,9 and 12 hours, were probed with CMpLHCI:2 (Figure 3). Equal amounts of chlorophyll $(20 \mu \mathrm{g})$ were applied on the SDS-gel. The immunoblotting assay shows that the concentration of LCHI polypeptides as well as $\mathrm{Ch}_{a / h}-\mathrm{Pl}$, on a chlorophyll basis, was higher in 12 than in 6 hours greened plants.

We therefore isolated polyA ${ }^{*}$ RNA from plants that had received light for 6 as well as 12 hours. These RNA preparations were used to prime in vitro translation in a rabbit reticulocyte lysate. Both stimulated incorporation of radioactive methionine into TCA precipitable material by a factor of 7.5. There were only small differences in the polypeptide pattern of the total products of in vitro translation (Figure 4). When $1.25 \mu \mathrm{g}$ of CMpLHCI:2 was added to material containing $10^{6}$ TCA precipitable cpm of each of the in vitro translates the immunoprecipitate gave a radioactive band representing the LHCI precursor polypeptide. It was much less intense with RNA from 6 hours greened plants than after 12 hours greening (Figure 5, lanes 1 and 2). Even though $\mathrm{CMpLHCI} 22$ reacts with several polypeptides in the thylakoid membrane (Figures 2 and 3) only one radioactive band is seen, representing one or more precursor polypeptides with the same apparent molecular weight of $28 \mathrm{kD}$. The molecular weights of the mature polypeptides in the barley thylakoid membranes, when solubilized in SDS alone, are 23-24 kD.

The Triton-X100 solubilised LHCI polypeptides present in the PSI-200 preparation (Figure 2 , lanes 1,4 ) have an electrophoretic mobility different from that of the LHCI polypeptides solubilised in SDS from thylakoids (Figure 2, lanes 2,5 ). What the change in mobility is due to is not clear, but it is always observed $(4,14)$. Figure 2 shows that $\mathrm{CMpLHCI}: 2$ reacts with the 


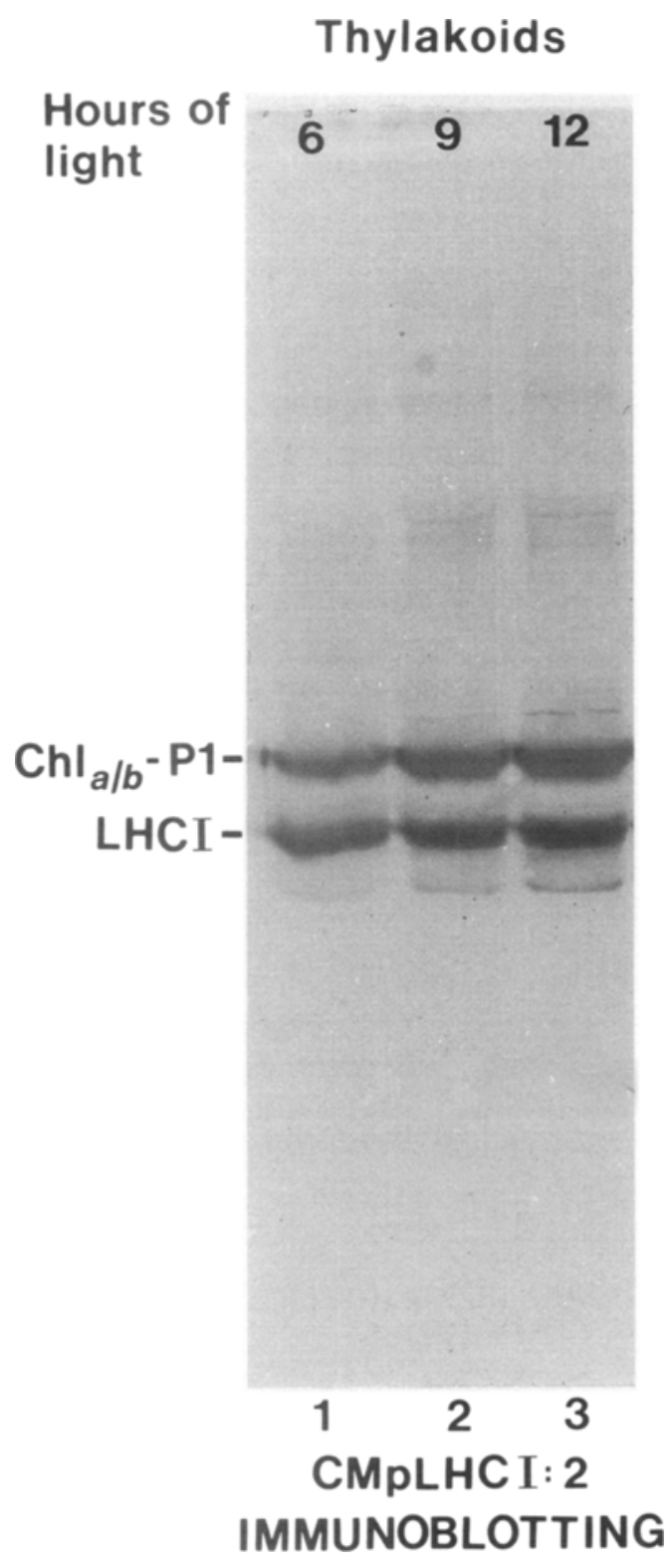

Figure 3. Concentration of LHCI and $\mathrm{Chl}_{a / b}-\mathrm{P} 1$ in greening barley.

Thylakoid polypeptides from wild-type seedlings (20 $\mu \mathrm{g} \mathrm{Chl)} \mathrm{illuminated} \mathrm{for} 6,9$ or 12 hours were separated on 11-15\% SDS-PAGE prior to electroblotting. The nitrocellulose filter was probed with $150 \mu \mathrm{g}$ of CMpLHCI:2,

\section{Translation products}

\section{Hours of light}

612
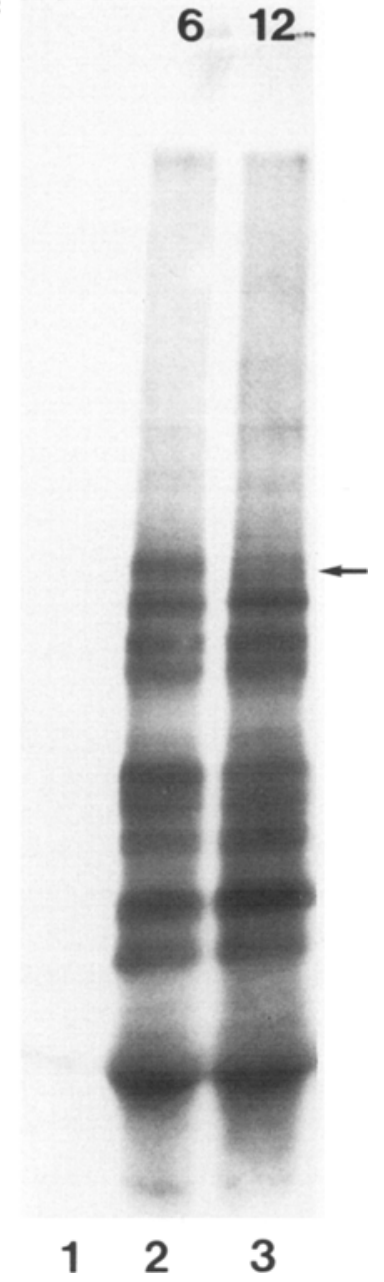

Figure 4. Total translation products.

Autoradiogram of in vitro translated polypeptides in a rabbit reticulocyte lysate separated on $8-25 \%$ SDS-PAGE. In lane 1 no RNA was added. In lanes 2 and 3 polyA+ RNA isolated from 6 and 12 hours greened barley was used. The arrow indicates the only visible difference in the polypeptide pattern. 


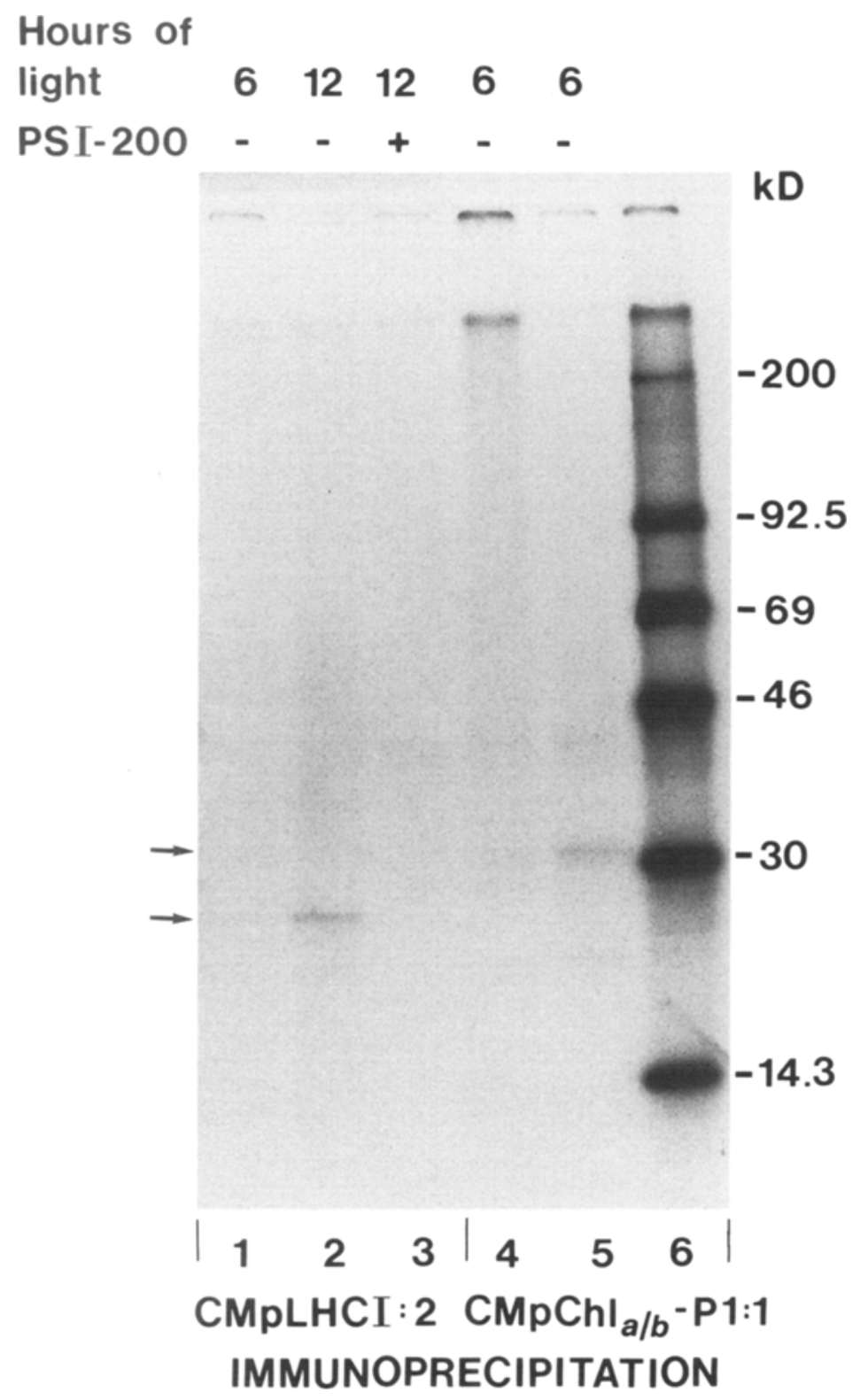

Figure 5. Immunoprecipitation of the precursor polypeptides for barley $\mathrm{LHCl}$ and $\mathrm{Chl}_{a / b}-\mathrm{Pl}$.

The ${ }^{35}$ S-labelled products are separated by $8-25 \%$ SDS-PAGE. PolyA ${ }^{+}$RNA isolated from plants illuminated for 6 (lanes 1, 4 and 5) and 12 (lanes 2 and 3) hours was used as templates for in vitro translations. The autoradiogram shows immunoprecipitated polypeptides using $1.25 \mu \mathrm{g}$ of CMpLHCI:2 (lanes 1, 2 and 3) and $1.25 \mu \mathrm{g}$ of $\mathrm{CMpCh}_{a / b}-\mathrm{P} 1: 1$ (lanes 4 and 5). In lane 3, $40 \mu \mathrm{g}$ of PSI-200 was added to the antibody prior to immunoprecipitation. Lane 6 shows ${ }^{14} \mathrm{C}$-methylated standard proteins for molecular weight determination. 


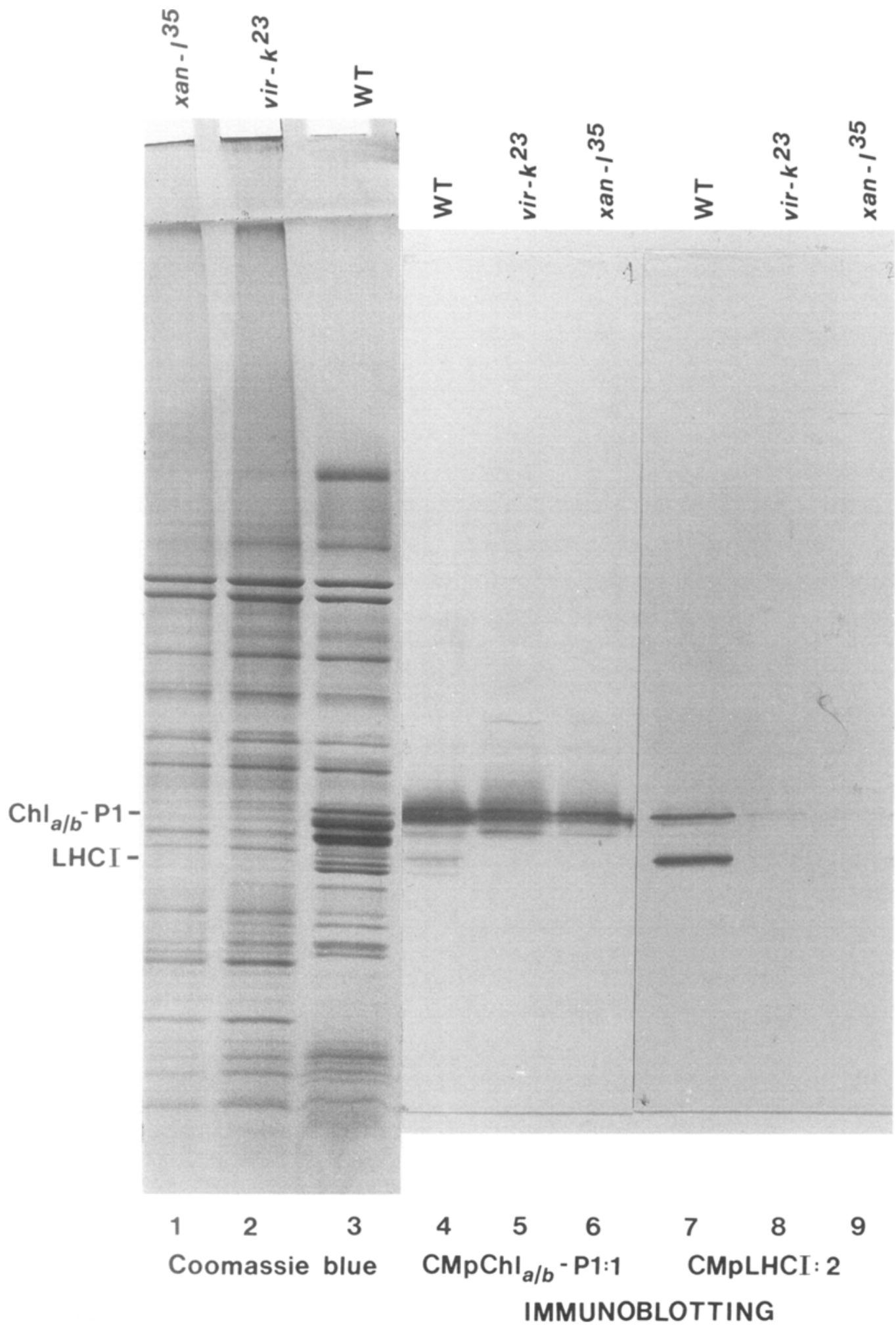


Figure 6. Absence of LHCI in the nuclear gene mutants viridis- $k^{23}$ and $x a n t h a-l^{35}$.

Thylakoid polypeptides from $x a n$ tha- $^{35}$, viridis- $k^{23}$ and wild-type(WT) barley seedlings were separated on $8-25 \%$ SDS-PAGE. Lanes 1, 2 and 3 are stained with Coomassie blue. After electroblotting the nitrocellulose sheets were probed with $150 \mu \mathrm{g}$ of $\mathrm{CMpCh}_{a / h}$-P1:1 (lanes 4, 5 and 6) and $150 \mu \mathrm{g}$ of CMpLHCI:2 (lanes 7, 8 and 9).

LHCI polypeptides of the antigen preparation, PSI-200. When $40 \mu \mathrm{g}$ of total PSI-200 protein was incubated with $1.25 \mu \mathrm{g}$ of CMpLHCI:2 prior to the addition to the translate, no precipitation band was seen (Figure 5, lane 3). The PSI-200 preparation is devoid of $\mathrm{Chl}_{a / b}-\mathrm{P} 1$ (Figure 2, lane 4) and the precursor protein that is competed out (Figure 5, lane 3) can therefore only be the precursor for LHCI. Thus, the epitope that is recognized by CMpLHCI:2 both in mature $\mathrm{Chl}_{a / b}-\mathrm{Pl}$ and $\mathrm{LHCI}$, is not exposed in the precursor of $\mathrm{Chl}_{a / b}-\mathrm{Pl}$. It was therefore of interest to see, if the common epitope, recognized by $\mathrm{CMpChl}_{\alpha / b}-\mathrm{Pl}$, would be exposed in the precursor proteins. In Figure 5, lane 4, $1.25 \mu \mathrm{g}$ $\mathrm{CMpChl}_{a / b}$-P1:1 was added to TCA precipitable material containing $10^{6} \mathrm{cpm}$ of the in vitro translate primed with polyA ${ }^{+}$RNA from 6 hours greened plants. Very weak, if any bands were observed on the autoradiogram (Figure 5, lane 4). The assay was therefore scaled up and $1.25 \mu \mathrm{g}$ $\mathrm{CMpChl}_{a / b}-\mathrm{Pl}: 1$ was added to $9 \times 10^{6}$ TCA precipitable cpm. A polypeptide of apparent molecular weight $31 \mathrm{kD}$ was specifically precipitated. No polypeptide of $28 \mathrm{kD}$ was seen (Figure 5 , lane 5). When CMpLHCI:2 was added to this translate the $28 \mathrm{kD}$ polypeptide was precipitated (data not shown).

The absence of the LHCI polypeptides in the nuclear gene mutant viridis- $k^{23}$ has previously been established (14). This mutant was used to demonstrate that the presence of $\mathrm{LHCl}$ is corre-

Figure 7. Presence of transcripts for $\mathrm{LHCI}$ in viridis $-k^{23}$ and xantha-lis.

The ${ }^{35}$-labelled products are separated by $8-25 \%$ SDS-PAGE. The autoradiogram shows immunoprecipitations using $1.25 \mu \mathrm{g}$ of $\mathrm{CMpLHCl}: 2$ for in vitro translation experiments primed with polyA $\mathrm{A}^{+} \mathrm{RNA}$ from viridis- $k^{23}$ (lane 1), xantha- ${ }^{35}$ (lane 2 ) and wildtype barley leaves (lane 3 ). The arrow indicates the position of the LHCI precursor polypeptide.

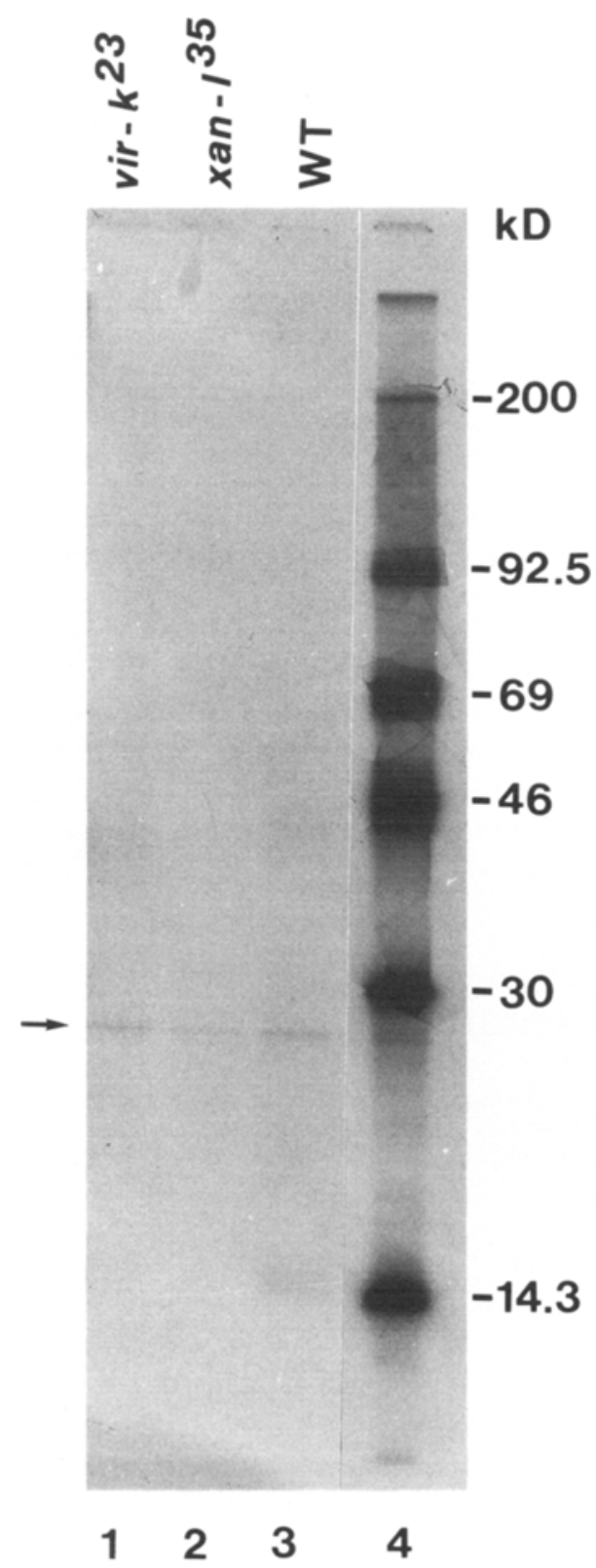

CMpLHCI: 2

IMMUNOPRECIPITATION 
lated with the presence of a $730 \mathrm{~nm}$ fluorescence emission at $77 \mathrm{~K}$ (14). A mutant with a similar phenotype but in a different gene, xantha- $l^{35}$ also lacks the $730 \mathrm{~nm}$ fluorescence emission at 77 K (D.J. SimPSON, personal communication) and is likewise found to be devoid of LHCI polypeptides (Figure 6, lane 9), and to contain $\mathrm{Chl}_{a / b}-\mathrm{P} 1$ (Figure 6, lane 6). It was therefore of interest to see, if these two mutants contained transcripts for the precursor of LHCI. PolyA ${ }^{+}$ RNA from mutant seedlings that had been greened for 12 hours, was isolated and used to prime in vitro translations. CMpLHCI:2 precipitated a polypeptide with an apparent molecular weight of $28 \mathrm{kD}$ in translates primed with wild-type as well as both mutant polyA ${ }^{+}$RNA's (Figure 7).

\section{DISCUSSION}

In barley the two LHCI proteins differ in their long wave-length fluorescence emission at $77 \mathrm{~K}$ and their polypeptide composition. The LHCI680 contains two and the LHCI-730 three polypeptides, differing in electrophoretic mobility (4). However, all LHCI polypeptides show structural homology as evidenced by monoclonal antibody cross-reactivity (Figure 2). When we used these monoclonal antibodies for immunoprecipitation of in vitro synthesized apoproteins, only one band appeared on the autoradiogram. This represents either one precursor polypeptide of apparent mol.w. $28 \mathrm{kD}$, or two or more precursor polypeptides which happen to have identical electrophoretic mobility (Figure 5). With our panel of monoclonal antibodies to LHCI it has not been possible to distinguish between the two possibilities.

The possiblity that there is only one precursor polypeptide for the LHCI is supported by the observation that two tomato LHCI clones encode identical precursor proteins (19). The authors isolated the clones employing a polyclonal antibody to Vicia faba LHCI. This antibody was used to detect fusion proteins made by $\lambda$ phages containing inserts of tomato cDNA (9). The cDNA clone isolated, Cab-6A, was used as a probe in Southern blots of tomato DNA fragmented with restriction enzymes. Two or more fragments hybridized with every restriction en- zyme used. It was not possible to isolate the genomic clone corresponding to Cab-6A, but another $\mathrm{Cab}-6 \mathrm{~B}$, which contains three introns. The two genes differed by eight nucleotides within the coding region, but they encoded identical proteins (19).

If there is only one LHCI precursor polypeptide, that must be post-translationally processed to yield the five mature polypeptides. Such a mechanism has been shown to occur for a precursor protein of LHCII. One genomic clone of Lemna LHCII, pAB30, was in vitro transcribed and translated. The in vitro translated precursor protein was taken up by Lemna chloroplasts, processed and inserted into the thylakoid membrane. The precursor protein was cleaved at several sites, giving rise to at least three mature polypeptides of slightly different electrophoretic mobility (16). Similar experiments have been carried out using a petunia cDNA clone encoding the precursor polypeptide to LHCI of apparent mol.w. $29 \mathrm{kD}$. When this precursor protein was taken up by the chloroplasts and processed, it gave rise to only a single polypeptide of $24 \mathrm{kD}$ (23).

Barley LHCI and $\mathrm{Chl}_{a / b}-\mathrm{P} 1$ have at least two epitopes in common (14). It is therefore surprising that the monoclonal antibody CMpLHCI:2 only precipitates the precursor of LHCI, whereas $\mathrm{CMpCh}_{a / b}-\mathrm{P} 1: 1$ only precipitates the precursor of $\mathrm{Chl}_{a / b}-\mathrm{P} 1$. The size of this previously not described precursor protein is $31 \mathrm{kD}$ and the mature protein is $28 \mathrm{kD}$. This differential antibody reactivity to the precursor polypeptides, but not their mature forms, could be due to shielding of epitopes in the precursor proteins as a result of folding even in the $0.2 \%$ SDS used in immunoprecipitation. These epitopes could be exposed, when the mature proteins are immobilized in a denatured state on the nitrocellulose filters after electroblotting.

The two non-allelic mutants, viridis $k^{23}$ and xantha- $l^{35}$ are devoid of LHCI polypeptides in their membranes as detected by immunoblot assays. However, the immunoprecipitation experiments, using the in vitro translates of the mutants, have shown that the transcripts for LHCI are present. One could speculate that the low chlorophyll content of these mutants prevents the insertion of $\mathrm{LHCI}$ polypeptides into 
their membranes. That would indicate that this chlorophyll deficiency has a specific effect on the insertion of $\mathrm{LHCI}$, since $\mathrm{Chl}_{a / b}$-P1 is incorporated. It has been shown that the in vitro up-take and processing of Lemna LHCII is greatly enhanced in the presence of $\delta$-amino-levulinate, a precursor, and S-adenosyl-methionine, a cofactor of chlorophyll biosynthesis (16). Chlorophyll $a$ is also necessary for the accumulation of the plastid encoded chlorophyll $a$-apoproteins (15). A chlorophyll-deficient barley mutant, xantha- $f^{10}$, failed to accumulate radiolabelled chlorophyll $a$-apoproteins in the light, even though transcripts for these apoproteins were present. The complete block in xantha-f $f^{10}$ is between protoporphyrin IX and Mg-protoporphyrin IX, whereas the step affected in the two barley mutants we have studied is a leaky block between Mg-protoporphyrin IX and protochlorophyllide leading to limitation in chlorophyll availability. To clarify why viridis- $k^{23}$ and xantha- $l^{35}$ do not incorporate LHCI into their membranes, we would like to isolate cDNA clones encoding LHCI. These would then be used for in vitro transcription and translation followed by up-take experiments using plastids of viridis- $k^{23}$ and $x a n t h a-l^{35}$. By including precursors and co-factors of chlorophyll-biosynthesis, we hope to find the component necessary for the up-take and processing of barley LHCI.

\section{ACKNOWLEDGEMENTS}

We wish to thank Professor DITER vON Wettstein, Carlsberg Laboratory, Copenhagen, Denmark for his encouragement during the course of this work and critical reading of the manuscript. We are indebted to Dr. DAvID SIMPSON, Carlsberg Laboratory, Copenhagen, Denmark for advice in preparing Figure 1. We are grateful to TOM BEKTVED for excellent technical assistance and to LISE TRILLOT, NINA RASMUSSEN and ANN-SOFI STEINHOLTZ for manuscript and figure preparation.

\section{REFERENCES}

1. ARNon, D.I: Copper enzymes in isolated chloroplasts. Polyphenoloxidase in Beta vulgaris. Plant Physiol. 24, 1-14 (1949)

2. BASSI, R., O. MACHOLD \& D. SIMPSON: Chlorophyllproteins of two photosystem I preparations from maize. Carlsberg Res. Commun. 50, 145-162 (1985)

3. Bassi, R., G. Høyer-Hansen, R. Barbato, G.M. GIACOMETTI \& D.J. SIMPSON: Chlorophyll-proteins of the photosystem II antenna system. J. Biol. Chem. 262, 13333-13341 (1987)

4. BASSI, R.\& D.J.SIMPSON: Chlorophyll-protein complexes of barley photosystem I. Eur. J. Biochem. 163, 221-230 (1987)

5. DARR, S.C., S.C. SOMMERVILle \& C.J. ARNTZEN: Monoclonal antibodies to the light-harvesting chlorophyll $a / b$ protein complex of photosystem II. J. Cell Biol. 103, 731-740 (1986)

6. Evans, P.K. \& J.M. ANDERSON: The chlorophyll $a / b$-proteins of PSI and PSII are immunologically related. FEBS Lett. 199, 227-233 (1986)

7. FLING, S.P. \& D.S. GREGERSON: Peptide and protein molecular weight determination by electrophoresis using a high-molarity tris buffer system without urea. Anal. Biochem. 155, 83-88 (1986)

8. Henningsen, K.W., J.E. Boynton, D. v. WETTSTEIN \& N.K. BOARDMAN: Nuclear genes controlling chloroplast development in barley. In: The Biochemistry of Gene Expression in Higher Organisms. J.W. Lee \& J.K. Pollak, eds., pp. 457-478. Australian and New Zealand Book Co., Sydney (1973)

9. Hoffman, N.E., E. Pichersky, V.S. Malik, C. Castresana, K. Ko, S.C. DarR \& A.R. Cashmore: A cDNA clone encoding a photosystem I protein with homology to photosystem II chlorophyll $a / b$-binding polypeptides. Proc. Natl. Acad. Sci. USA 84, 8844-8848 (1987)

10. Høyer-Hansen, G.: Monoclonal antibodies to chlorophyll $a$-protein 1 in barley. In: Advances in Photosystem Research, Vol. III, pp. 171-174. C. Sybesma ed., M. Nijhoff/Dr. W. Junk Publishers, The Hague, Netherlands. (1984)

11. Høyer-HANSEN, G. \& D.J. Simpson: Changes in the polypeptide composition of internal membranes of barley plastids during greening. Carlsberg Res. Commun. 42, 379-389 (1977)

12. Høyer-Hansen, G., L.S. HønBerg, D.J. Simpson: Monoclonal antibodies used for the characterization of the two putative iron-sulphur centre proteins associated with photosystem I. Carlsberg Res. Commun. 50, 23-35 (1985)

13. Høyer-Hansen, G., L.S. Hønberg \& P.B. Høנ: Probing in vitro translation products with mono- 
clonal antibodies to a $15.2 \mathrm{kD}$ polypeptide subunit of photosystem I. Carlsberg Res. Commun. 50, 211-221 (1985)

14. Høyer-Hansen, G., R. Bassi, L.S. Hønberg \& D.J. SIMPSON: Immunological characterization of chlorophyll $a / b$-binding proteins of barley thylakoids. Planta 173, 12-21 (1988)

15. KLeIN, R.R., P.E. Gamble \& J.E. Mullet: Light-dependent accumulation of radiolabeled plastid encoded chlorophyll a-apoproteins requires chlorophyll $a$ : I. Analysis of chlorophyll-deficient mutants and phytochrome involvement. Am. Soc. Plant Physiol. (submitted 1988)

16. KohoRn, B.D., E. HAREL, P.R. Chitnis, J.P.THORNBER \& E.M. TOBIN: Functional and mutational analysis of the light-harvesting chlorophyll $a / b$ protein of thylakoid membranes. J. Cell Biol. 102, 972-981 (1986)

17. MACHOLD, O.: Polypeptide composition of the photosystem I chlorophyll $a / b$-protein from three different plant species. Carlsberg Res. Commun. 51, 227-238 (1986)

18. Machold, O., A. Meister, H. Sagromsky, G. Høyer-Hansen \& D. v. Wettstein: Composition of photosynthetic membranes of wild-type barley and chlorophyll $b$-less mutants. Photosynth. 11, 200-206 (1977)

19. Pichersky, E., N.E. Hoffman, R. Bernatzky, B. Piechulla, S.D. Tanksley \& A.R. Cashmore: Molecular characterization and genetic mapping of DNA sequences encoding the type I chlorophyll $a / b$-binding polypeptide of photosystem I in $L y$ copersicon esculentum (tomato). Plant Mol. Biol. 9, 205-216 (1987)

20. RYRIE, I.J.: Immunological evidence for apoproteins of light-harvesting chlorophyll-protein complex in a mutant of barley lacking chlorophyll b. Eur. J. Biochem. 131, 149-155 (1983)

21. SIMPSON, D.J. \& D. . WETTSTEIN: Macromolecular physiology of plastids XIV. Viridis mutants in barley:genetic, fluoroscropic and ultrastructural characterization. Carlsberg Res. Commun. 45, 283-314 (1980)

22. Simpson, D.J., R. Bassi, O. Vallon \& G. HøyerHANSEN: Location and organisation of the chlorophyll-proteins of photosynthetic reaction centres in higher plants. In: Photocatalytic Production of Energy-Rich Compounds. Hall \& Grassi, eds, pp. 195-209. Elsevier Applied Science Publishers Ltd., Barking, England (1988)

23. StaYton, M.M., P. Brosio \& P. Dunsmuir: Characterization of a full-length petunia cDNA encoding a polypeptide of the light-harvesting complex associated with photosystem I. Plant Mol. Biol. 10, 127-137 (1987)

24. Towbin, H., T. Staehelin \& J. Gordon: Electrophoretic transfer of proteins from polyacrylamide gels to nitrocellulose sheets: Procedure and some applications. Proc. Nat. Acad. Sci. USA 76, 4350-4354 (1979)

25. Wettstein, D. v., K.W. Henningsen, J.E. BoynTON, G.C. KanNangara \& O.F. Nielsen: The genic control of chloroplast development in barley. In: Autonomy and biogenesis of mitochondria and chloroplasts. N.K. Boardman, A.W. Linnane \& R.M. Smillie eds., pp. 205-223 (1971) North Holland

26. White, M.J. \& B.R. GreEN: Antibodies to the photosystem I chlorophyll $a+b$ antenna cross-react with polypeptides of CP29 and LHCII. Eur. J. Biochem. 163, 545-551 (1987) 